\title{
A LENTI TERMÁLFÜRDŐ VENDÉGELÉGEDETTSÉGI VIZSGÁLATA A FÖLDRAJZI TÉRREL ÖSSZEFÜGGŐ EGÉSZSÉGTURISZTIKAI TERMÉKFEJLESZTÉS STRATÉGIAI IDŐSZAKÁBAN
}

\author{
VIZI ISTVÁN - STRACK FLÓRIÁN \\ GUEST SATISFACTION SURVEYS OF THE LENTI THERMAL SPA \\ IN THE STRATEGIC PERIOD OF \\ GEO-SPATIAL ORIENTED HEALTH TOURISM PRODUCT DEVELOPMENT
}

\begin{abstract}
This article examines the challenges of today's dynamically improving Hungarian tourism successes and results - visitor numbers, guest nights, and revenue growth - in a particular geographical location and space, the Hungarian-Austrian-Slovenian-Croatian border. The presentation of the guest satisfaction measurement results of the Lenti Thermal Spa and Szent György Energy Park highlights the complex process of developing a health tourism product. Health tourism is one of the most significant areas of tourism specified by the National Tourism Development Strategy 2030. The guest satisfaction survey presented in this study played an important role in providing appropriate feedback from the guests for the large-scale developments that were planned. Furthermore, the result of it strengthened the management, and the owner of the spa that the planned modernization, renovation, and development projects foresees the creation of a unique and cost-efficient product mix that will be successful on the domestic market based on the objectives of the National Tourism Development Strategy 2030.
\end{abstract}

Keywords: NTS 2030, geographical space, health tourism, guest satisfaction, Lenti

\section{Bevezetés}

Tanulmányunk azt vizsgálja, hogy egy a vendégek elégedettségét vizsgáló méréssorozat hogyan tud a Nemzeti Turizmusfejlesztési Stratégia 2030 célkitúzésének szellemiségében - országkapu a földrajzi térben - támogatni egy egészségturisztikai termékkínálatban és termékfejlesztésben érintett kisvárost. A tanulmány fókuszpontjába helyezett kisváros, Lenti a rendszerváltást követő évtizedekben kilépett a korábbi vasfüggöny mögötti katonavárosi miliős földrajzi elszigeteltségéből. A földrajzi tér hosszú évtizedek elzártsága után kinyílott. A hármas határ mentén fekvő település jelenleg Magyarország dinamikusan fejlődő turisztikai kapuja a Nyugat- és Délnyugat-Európa irányából érkező vendégek részére, amihez hozzájárul a térségben összekötő kapocsként több évtizede múködő egészségturisztikai objektumrendszer (fürdő, gyógyászat, strand, Szent György Energiapark, kemping, szálloda).

Lenti hosszú távú településfejlesztési koncepciója (2016-2030) alapján stratégiai fejlesztési prioritás a város gazdasági potenciáljának növelése, különös figyelemmel a természeti értékeken alapuló aktív és egészségturisztikára, egy turisztikai központ kialakítására, valamint rendezett és élhetó kisvárosi környezet megteremtésére. Ehhez nagy előrelépést jelentett a város 2016. évi hivatalos gyógyhellyé nyilvánítása. Lenti céljai között szerepel, hogy a gyógyhelyi kínálat még hiányzó elemeinek létrehozását célzó beruházások sora valósuljon meg országkapu-térségi funkciókkal, szerepekkel és felelősséggel. A település és a térség fejlődésének tehát az egyik fó előmozdítója és zászlóshajója az 1978-ban megnyílt, majd folyamatosan bővült Lenti Termálfürdő és Szent György Energiapark. A növekedés- 
nek további jelentős dinamizáló tényezője a 2016 nyarán átadott, négycsillagos Thermal Hotel Balance szálloda múködése; 2018-ban a település vendégéjszakáinak 41\%-a ebben hotelben realizálódott. Egészében véve is 2016 és 2018 között a vendégéjszakák száma 170\%-kal nőtt. A szálloda és a település vendégforgalma további minőségi változásának, növekedésének azonban az egyik gátja a markáns minőségi különbség a felújítás előtt álló Termálfürdő jelenlegi múszaki, esztétikai és vendégfogadási feltételeinek állapota és a szálloda szolgáltatási színvonala és portfóliója között. A Termálfürdőben a mennyiségi növekedés jelenleg még töretlen, viszont ez a növekedés minőségi fejlesztések nélkül egy ponton hamarosan visszaesik, már csak azért is, mert a földrajzilag nem távoli nyugat-dunántúli és kiváló színvonalú stájer és burgenlandi fürdőkomplexumok ebben a versenyben kisebb-nagyobb, illetve rendkívüli versenyelőnnyel rendelkeznek.

Jelen tanulmány azt mutatja be, hogy a gyógyhely mostani állapotában milyen vendégelégedettségi és fogyasztói magatartási jellemzők jelennek meg, amelyek a jövőbeni további mennyiségi és minőségi fejlesztések vendégoldali figyelembevétele tekintetében elengedhetetlenek.

\section{Az egészségturizmus rendszere}

Az egészségturizmus a 21. század turizmusának egyik legfontosabb és leggyorsabban fejlődő ágazata. Viszonylag új jelenségről van szó, hiszen az egészségturizmus és altípusai csupán az elmúlt néhány évtized során váltak igazán népszerúvé. Ennek egyik fő oka, hogy olyan összetett fogalomról beszélünk, aminek kapcsán hosszú ideig nem született egyetértés sem a turisztikai, sem pedig egészségügyi körökben, noha lényegének meghatározásával több kutató (RÁTz T. 2001, SMith, M.-PuCzKó L. 2009, ConNELL, J. 2011) is próbálkozott. Az Önkormányzati és Területfejlesztési Minisztérium által 2007-ben megjelentett Országos Egészségturizmus Fejlesztési Stratégia (OEFS) szerint „az egészségturizmus a gyógy- és wellnessturizmust átfogó fogalom, a turizmusnak azon területét jelenti, ahol a turista utazásának fô motivációja az egészségi állapotának javítása és/vagy megôrzése, tehát a gyógyulás és/vagy megelőzés és ennek megfelelően a célterületen tartózkodása alatt igénybe is vesz egészségturisztikai szolgáltatás(oka)t” (p.9). Más megfogalmazásban az egészségturizmus fogyasztóinak alapvető célja a betegségek megelőzése, az egészségi állapot szinten tartása, illetve helyreállítása (SzABó Z. 2011).

Az egészségturizmus rendszerén belül két, egymástól alapvetően eltérō, de hasonlóságokat is mutató altípust különböztethetünk meg. Ezek egyike a gyógyturizmus, amely főként a már kialakult krónikus betegségekben szenvedők számára kínál természetes gyógytényezőkre (pl. víz, éghajlat, barlang, iszap stb.) épülő szolgáltatásokat. A gyógyturizmus fogyasztóinak elsődleges célja természetesen a teljes, vagy részleges gyógyulás, ebből következően a gyógyturizmus olyan utazás, amelynek célja az egészség javítása. Az egészségturizmus e típusa tehát az igénybe vett szolgáltatások révén legalább két szektort (turizmus és egészségügy) érint (BoOKMAN, M. Z.-BOOKMAN, K. R. 2007) és valójában összeköti a kellemest a hasznossal, hiszen az alapvetóen gyógyturisztikai céllal utazó fogyasztók tartózkodása során szabadidős elemek (aktív turizmus, kulturális turizmus stb.) is megjelennek (LACZKó T.-BÁNHIDI M. 2015, DEMicCO, F. J. 2017). A másik nagy alcsoport a wellnessturizmus, amely a pihenésre, kikapcsolódásra vágyó, az egészségmegőrzést célul kitűző fogyasztók számára kínál szolgáltatásokat (MÜLLER, H.-LANZ KAUFMANN, E. 2001, KARDOS Z-NÉ 2011). A wellnessturizmus lényegi eleme a felfrissülés és a megújulás, eredeti, meghatározása szerint a cselekvésnek olyan integrált módja, amely az egyénben rejlő lehetőségek maximalizálására irányul (DunN, H. L. 1961). Különösen fontos, hogy 
a wellness nem csupán az utazások során, hanem a mindennapokban is megjelenhet. PimPale, V. K. (2016) szerint a wellness központi eleme az az életstílus, amely holisztikus szemléletet követve a test, a lélek és a szellem egyensúlyának megteremtését túzi ki célul. A wellnessturizmus céljai összetettek, egyaránt részei a prevenció, regeneráció, rekreáció és relaxáció (Boros Sz. et al. 2012; RUSZINKó Á.-DonKA A. 2019). Ahogyan korábban már utaltunk rá, az altípusok között nem minden esetben húzódik éles határvonal, sőt nem is érdemes élesen szétválasztani a kettőt, hiszen a keresleti trendek vizsgálatai során egyértelmúvé vált, hogy közöttük olykor jelentős átfedések figyelhetők meg, illetve egyre hangsúlyosabbá válik az átfogó wellness élmény iránti kereslet (REISMAN, D. A. 2010; SzIVA I. 2010), ez visszaigazolható a magyarországi közfürdőkben is.

Az egészségturisztikai szolgáltatásokat fogyasztó turisták élményeit természetesen a kiegészítő szolgáltatásként igénybe vett, a turizmus más területeihez kapcsolódó tevékenységek is befolyásolják, amelyek mindenképpen szükségesek az egészségturizmusban érdekelt szolgáltatók sikeréhez. Lényeges még, hogy a fogyasztói élményre az egyéni jóllétet befolyásoló tényezők, pl. a környezet, munkahely, család, lelkiállapot, fizikai állapot, stb. is hatással vannak, így az ezekből adódó negatív hatásokat a tartózkodás során a szolgáltatóknak a siker érdekében minimalizálniuk kell.

\section{Klasszikus egészségturisztikai termékeink Magyarországon: fürdók és gyógyfürdók}

A magyarországi egészségturizmus zászlóshajójának tekintett közfürdő-üzemeltetés a 21. század második évtizedében társadalmi, gazdasági, demográfiai és még számos további tényező hatására kiemelt kihívások előtt áll. Ez alól a több évtizede sikeresen múködő Lenti Termálfürdő és a Szent György Energiapark - amelynek üzemeltetôje a Lenti Gyógyfürdő Kft. - sem kivétel.

Az egészségturisztikai kínálat elemei közül a fürdőzésnek, avagy másképpen megfogalmazva a természetes termálvízen, illetve gyógyvízen alapuló turisztikai kínálatnak és a kialakult turisztikai termékrendszernek számos kihívója (versenytársa, konkurenciája) született az elmúlt években. Olyan kihívások, amelyek tekintetében ma már nem helytálló az a klasszikus sztereotípia, ami szerint jó időben (elsősorban a nyári kánikulában) az egyetlen üdvözítő módja a szabadidő eltöltésének a fürdőben keresett húsölés és szórakozás, valamint hogy a hűvös, hideg ôszi és téli napokon a gőzben gomolygó melegvizes termál- vagy gyógymedencék és hangulatos szaunakabinok adnak csak vigasztalást. A közfürdőben eltöltött szabadidő számos formája ma már nem az egyedüli szabadidős lehetôség. A különböző betûjellel megjelölt (megbélyegzett és sokszor skatulyába szorított) generációk nagyon különbözően gondolkodnak a közfürdőkről és az ott megtalálható szolgáltatásokról. Az egyén a Maslow-féle piramisnak jelenleg is számos „emeletén” keresi a különböző lehetőségeket. A társadalom jelenlegi gazdasági helyzetében pedig jelentősen erősödik a szabadidő eltöltésére költhető diszkrecionális jövedelem. Ebben a versengésben alapvetésként a magyarországi fürdőszektornak nemcsak a vetélytársak miatt szükséges minőséget biztosítani.

\section{A hazai fürdók és gyógyfürdők helyzete}

Magyarországon sok fürdő és azon belül gyógyfürdő található (1. ábra). de a hétköznapi vélekedéssel ellentétben az elmúlt öt év során a Központi Statisztikai Hivatal (KSH) adatai alapján ezek száma folyamatosan csökkent (2.ábra). A fürdők legjellemzőbb szolgáltatásai a welnessturizmushoz, az egészségmegőrzéshez kapcsolódnak, ami az összes 


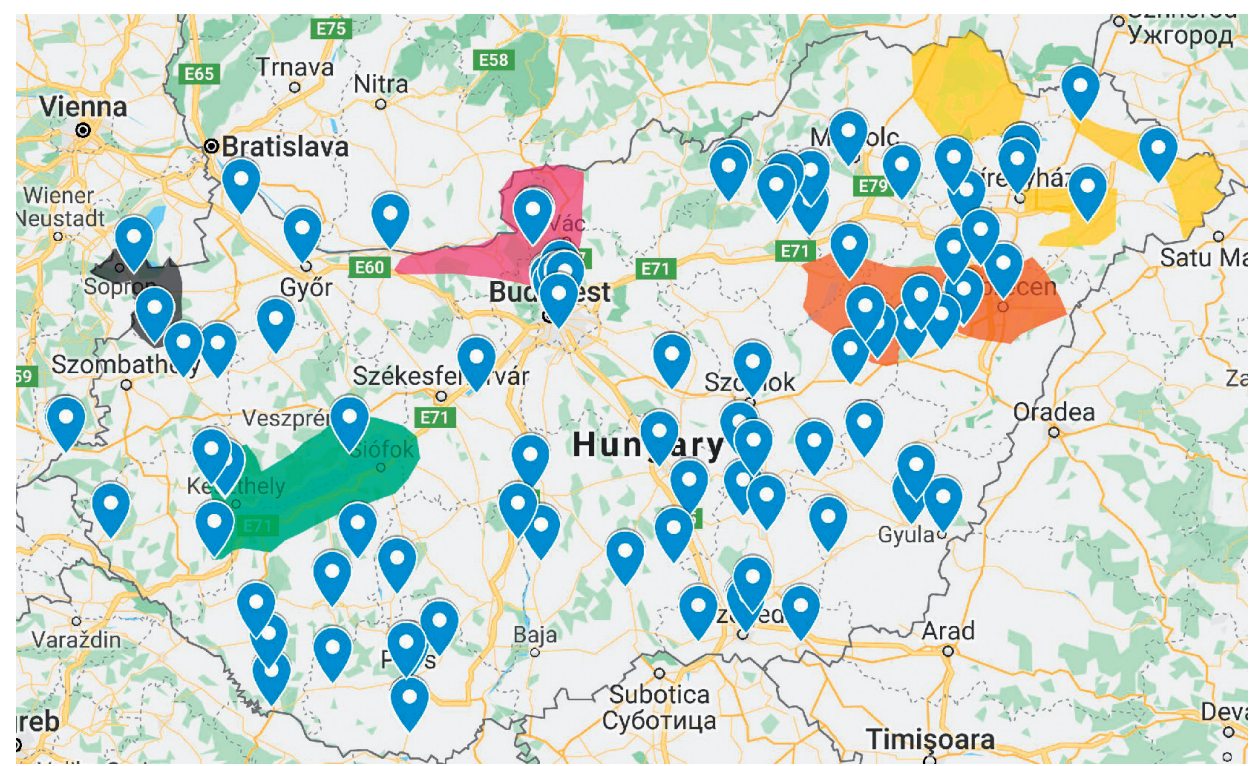

1.ábra Magyarország minősített gyógyfürdői és kiemelt turisztikai fejlesztési térségei. Forrás: szerk. VIZI I.-STRACK F. Figure 1 Certified spas and priority tourism development areas of Hungary. Source: ed. by VizI, I.-STRACK, F.)

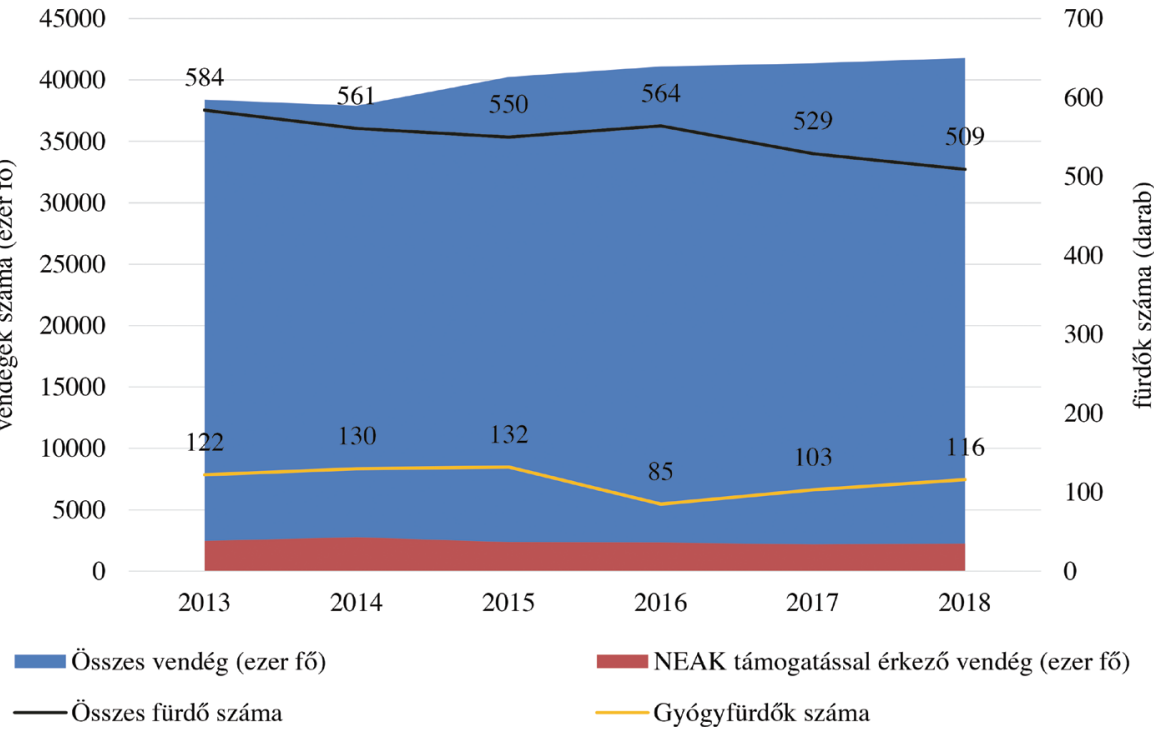

2. ábra Hazai fürdők és fürdővendégek számának alakulása 2013-2018 között Forrás: a KSH adatai alapján szerk. VIZI I.-STRACK F.

Figure 2 Changes in the number of domestic spas and spa guests between 2013-2018 Source: ed. by VIZI, I.-STRACK, F. based on KSH

hazai fürdő 50\%-ában elérhető. Ezt követi a gyógykezelés (25\%), valamint az orvosi vizsgálat, amit a fürdők 19\%-a kínál a fogyasztók számára (ksh.hu). Az elmúlt 5 évet tekintve azonban az is megfigyelhetô, hogy míg a fürdők száma folyamatosan csökkent, addig a vendégek 
száma, ha kis mértékben is, de emelkedő tendenciát mutat; ugyanakkor ezen belül a Nemzeti Egészségbiztosítási Alapkezelő (NEAK) támogatásával érkező fogyasztók száma csekély mértékben ugyan, de évről évre csökken (ksh.hu). A 2.ábrát vizsgálva az is megfigyelhetô, hogy a KSH gyógyfürdőszámra vonatkozó számadatai eltérnek az Állami Népegészségügyi Tisztiorvosi Szolgálat (ÁNTSZ) nyilvántartásától. Ennek lehetséges oka, hogy az ÁNTSZ legfrissebb, a gyógyfürdőket számba vevő nyilvántartása (antsz.hu) 2017 februárjában készült.

Fontos megemlíteni, hogy a 2014-2017 közötti időszakban a magyar fürdők árbevétele dinamikus növekedést mutatott, mintegy 34\%-kal nőtt, ugyanakkor a fürdők árbevételének viszont mindössze 9\%-a származott valamilyen gyógyászattal vagy egészségmegórzéssel kapcsolatos szolgáltatásból és alig 28\%-a fürdőszolgáltatásból, viszont 48\%-a szálláshely-szolgáltatásból (KSH 2016).

\section{Lenti Termálfürdö és Szent György Energiapark}

A vizsgálat helyszínét, amely az Országos Tisztifőorvosi Hivatal jegyzékében „Gyógyhely Lenti" névvel szerepel, a turisztikai vonzerőre, az éghajlati és életföldrajzi viszonyokra, valamint a minősített gyógyvíz jelenlétére alapozva a KEF-6384-4/2016 számú határozattal minősítették gyógyhellyé (antsz.hu). A gyógyhely központját, s egyben a város legjelentősebb idegenforgalmi attrakcióját a Lenti Termálfürdő és Szent György Energiapark adja, amelynek 9 ha-os területén 5 szabadtéri és 8 fedett medence található. A gyógyvíz mozgásszervi,ízületi és degeneratív gerinc megbetegedések kúraszerű kezelésére alkalmas. A fürdőkomplexum szabadtéri részlege gyermek-, úszó-, élmény-és gyógymedencékkel, valamint egy félig fedett hidromasszázs élménymedencével rendelkezik, melyhez 8 ha zöldterület tartozik. A fürdő legnagyobb medencéje $1340 \mathrm{~m}^{2}$ vízfelületű, amelyhez vadvízáram, nyakzuhany, csúszda és több masszázspad is tartozik. A $4700 \mathrm{~m}^{2}$ területú fedett fürdőrészben gyógyászati részleg, szépségfarm, szauna és 8 medence - köztük úszó-, gyógy-, gyermek-, tan- és hidromasszázs medencék, csúszdás élménymedence, jacuzzi - található, valamint egy $630 \mathrm{~m}^{2}$ területű pihenőtér. A fedett úszómedencét $28^{\circ} \mathrm{C}$, a gyógy- és a hidromasszázs medencéket $38^{\circ} \mathrm{C}$, a tan- és gyermekmedencét pedig $34^{\circ} \mathrm{C}$ hőmérsékletű vízzel töltik fel. A jelenleg üzemelő medencék teljes egyidejű terhelhetősége nyáron mintegy 3000, télen kb. 430 fő (lentifurdo.hu).

A Lenti Termálfürdő és Szent György Energiapark - más hazai fürdőkkel ellentétben alternatív termék- és szolgáltatáskínálattal szólítja meg azon vendégeket, akik a klasszikus nagy forgalmú és tömegekre építő fürdők (pl. Bükfürdő, Zalakaros, Sárvár) helyett az intim, csendes helyszínt, a személyes figyelmet és a családias környezetet létesítik előnyben, valamint az ilyen légkörben történő kikapcsolódást és pihenést keresik. A termálfürdőt azonban az Energiapark teszi Európában egyedülállóvá, mivel - a lentifurdo.hu szerint olyan jótékony hatású energiavonalak találkozási pontjaiban fekszik, ahol a vendégek a gyógyvíz és e különleges energetikájú hely együttes hatása miatt hatékonyabban tudnak pihenni, feltöltődni, gyógyulni. A vonzerőt növeli, hogy a fürdő rendelkezik saját szálláshelykínálattal is: a 92 szobás, négy csillagos Thermal Hotel Balance szálloda közvetlen összeköttetésben van a Fürdővel. A szálláshely-szolgáltatás része még egy 15 szobás panzió (Lenti Thermálpanzió) is. Ezen túl a fürdő fedett részében étterem is található, a szabadtéri részen pedig elsősorban a nyári időszakban számos vendéglátóegység üzemel. A fürdőhely nemzetközi népszerűségét és egyben a jövőbeni fejlesztések indokoltságát jól mutatja, hogy a külföldi vendégforgalom ranglistáján a legnépszerúbb termálfürdős települések között vendégéjszakák száma szerinti sorrendben a 9. helyezett, 52400 vendégéjszakával (KSH 2018), meglepő módon tehát a jóval híresebb Gyula és Harkány termálfürdős településekhez hasonló értéket mutat fel. 
A Nemzeti Turizmusfejlesztési Stratégia 2030 egyik célkitűzése, hogy a magyarországi turizmust ma jellemző térbeli (Budapest- és Balaton-központú), valamint idóbeli (májustól szeptemberig tartó, de főleg a július és augusztus hónapokat jelentő) egészségtelen koncentrációt csökkentse, ennek a célkitűzésnek felelnek meg a Lentiben tervezett, megvalósítandó fejlesztések is. A Stratégia célkitűzéseivel összhangban 2017-ben megkezdődött a jövőbeni fejlesztések tervezési szakasza. A tervezett korszerúsítési, felújítási és fejlesztési projekt megvalósulása lehetôvé teszi egy a hazai piacon sikeresen, költséghatékonyan és profitorientáltan múködtethető egyedi ,termékmix” létrejöttét, amelynek egyedisége a gyógyulás és pihenés együttesének komplex élményígéretében rejlik. Ez az élményígéret pedig kínálatot jelenít meg mind az egyre igényesebb, mind a magasabb fajlagos költésre képes külföldi és belföldi vendégek számára.

A tervezett fejlesztés középpontjában egyrészt a fürdó jelenlegi épített és természeti elemeinek (fedett fürdő, strandfürdő, camping, szálláshelyek, öltözők, medencék, gépészet, új nyári bejárat stb.) teljes körű, 21. századi színvonalú általános esztétikai és múszaki megújítása, másrészt pedig további két markáns elem, egy komplex, önállóan is igénybe vehető korszerű gyógyászati (döntően fürdőgyógyászati) központ, valamint egy új szaunakomplexum megvalósítása szerepel. A mintegy $1600 \mathrm{~m}^{2}$-es Szauna Park jövő́beni üzemeltetési filozófiájában és komplexitásában törekszik majd az osztrák-német fürdők által megjelenített egyediség, szellemiség, hangulat, térérzet és minőség biztosítására, amely rendszer vezeti és okítja a vendéget az élettanilag megfelelő használattal, illetve használatra. (Ennek a szaunakomplexumnak a szakmai koncepcióalkotója és tervezője VIzi IsTVÁN, a jelen tanulmány egyik szerzője). A gyógyászati és a wellness szolgáltató részleg teljes körű korszerúsítésének és bővítésének köszönhetően a fürdő a korábbi vendégkör mellett már képes lesz megcélozni a magasabb összegű kiadásokra is hajlandó (elsősorban külföldi) idősebb korosztályt is és a minőség felé való eltolódást támogató primer- és szekunder prevenciós célközönség aktívabb szerepét hozza majd magával. Az alkalmazott terápiák nem csak országosan, de határon túlnyúlóan is erősíteni fogják a létrehozandó komplexum egyediségét, tovább növelve a külföldi vendégek arányát.

\section{Fogyasztói magatartás és vendégelégedettség}

A fürdők állapotfelmérése során, a fejlesztési célkitűzések megfogalmazásakor és azok tervezésekor figyelembe kell venni a meglévő vendégkör fogyasztói jellemzőt is. A fogyasztók döntéseit számos tényező befolyásolja, amelyek közül a legalapvetôbbek a személyes, a pszichológiai, a kulturális és a társadalmi jellemzők. A személyes jellemzók közé sorolható a családi életciklus, a gazdasági körülmények, az életmód és a személyiség. A pszichológiai jellemzók esetén már megjelenik a motiváció, amely céltudatos cselekvésre ösztönzi a fogyasztókat. A turizmus tekintetében különösen fontos és ebbe a kategóriába tartozó fogalom még az attitúd, amely egy termékre, vagy szolgáltatásra vonatkozó pozitív, vagy negatív értékelés. A kultúra szerepe egyértelmú, hiszen az az ember viselkedésének egyik alapvetó, meghatározó eleme. A kultúrán belül különféle szubkultúrák is megfigyelhetők, amelyek kapcsolódhatnak például földrajzi régiókhoz, nemzeti, vagy vallási csoportokhoz. A társadalmi jellemzók tekintetében elsősorban a referenciacsoportok érdemelnek említést. Ezek a csoportok közvetett, vagy közvetlen hatást gyakorolnak a fogyasztóra. Ilyen csoportok lehetnek többek között a család, a barátok, az ismerósök és a munkahelyi közösségek (SZIGETI O.-SZAKÁLY Z. 2011).

A fent említett jellemzők természetesen nagyban képesek befolyásolni az adott vendég értékítéletét, elégedettségét is. A vendégek elégedettsége alapvető fontosságú az üzleti 
sikerhez. Ahhoz, hogy elégedetté váljon, a vendégnek legalább az általa elvárt minőséget kell kapnia (észlelnie) a tartózkodás során (NAGY Sz. 2016). A minőség vizsgálata esetén a vendég által érzékeltet kell összevetni az elvárásokkal, a minőség tehát a vendég elvárásai és tapasztalatai közötti különbség. Másképpen megközelítve minőség mindaz, amit a vendég annak tart, a vendég megítélése pedig szubjektív, így a minőség lényeges kritériuma a fürdővendég elégedettsége. Az elvárásokat értelemszerúen nagyon sok dolog befolyásolhatja (pl. korábbi tapasztalatok, szükségletek, mások véleménye, presztízs stb.). A szolgáltatás fogyasztása közben a vendég tapasztalatokra tesz szert, amelyek alapvetően meghatározzák a vendégek vásárlást követő magatartását is; pl. hogy törzsvendéggé válik-e vagy nem (Rudolfné KATONA M. et al. 2008; SzABó Z. 2018).

\section{A kutatás módszertana}

A kutatás során a kvantitatív kutatási módszerek közül kérdezőbiztos segítségével kitöltetett, magyar és német nyelvú, papír alapú kérdőíveket alkalmaztunk. A megkérdezés a Lenti Termálfürdő és Szent György Energiapark területén zajlott a 2017-es év tavaszi és nyári, valamint a 2018-as év tavaszi, nyári és őszi időszakaiban. A kitöltők mindnyájan a fürdő vendégei voltak. A kérdőív kérdései a demográfiai jellemzők mellett főként a vendégek elégedettségére irányuló kérdéseket tartalmaztak a fürdőre, a szolgáltatásokra és személyzetre vonatkozóan. A 2017-es évben 452 fő, a 2018-as évben pedig 854 fó vett részt a felmérésben. A tavaszi és őszi hétköznapi időszakban a fürdő vendégszámának ismeretében elmondható, hogy a kérdések a fürdőlátogatók jelentős részét elérték, a bérletes törzsvendégeket éppen úgy, mint a termálkemping elsősorban külföldi vendégeit.

A kérdőívek a múltbeli és a jövőben potenciálisan bekövetkező cselekvések mérésére tökéletesek, ugyanakkor jellemzően nem alkalmasak társadalmi cselekvések mérésére. A kérdőíves felmérésekre jellemző az alacsony szintű érvényesség és a magas szintû megbízhatóság (BABBIE, E. 2000). A kérdezőbiztos segítségével kitöltetett kérdőívek segítségével magasabb válaszadási arány érhető el, illetve csökken a félreértett kérdések száma, pontosabb eredmény érhető el, valamint alkalom nyílik a válaszadó megfigyelésére is. Ugyanakkor az ilyen jellegú felméréseknek veszélyei is vannak, különösen fontos, hogy a kérdezőbiztos semleges maradjon, munkáját kiemelkedő precizitással végezze, a válaszadó által közölt információkat pedig pontosan jegyezze le (MAJOROS P. 2011).

A kérdőívek eredményeinek elemzéséhez a demográfiai adatok közül a „,nem”, a „lakóhely” és a ,végzettség” adatok esetén az elégedettséggel való kapcsolatot kereszttábla-elemzéssel (Cramer-mutató) vizsgáltuk, amely két nominális, ordinális vagy kategorizált metrikus változó közötti összefüggés vizsgálatára alkalmas (SAJTos L.-Mitev A. 2007). Az „életkor” adatok esetén Kendall-féle rangkorrelációt alkalmaztunk, amely a változók közötti kapcsolat szorosságának mérésére a két változó rangszámainak különbségét használja fel. A Kendall- féle rangkorreláció a Spearman-féle korrelációs együttható alternatívája (FIDY J.-MAKARA G. 2005). ANOVA-elemzés, korreláció- és regresszióanalízis elvégzése nem volt lehetséges, mert a magyarázni kívánt változók nem mennyiségi változók.

\section{Eredmények}

Az eredmények ismertetése előtt megjegyzendő, hogy a 2017-es és a 2018-as felmérést megelőzően nem került sor hasonló vendégelégedettségi vizsgálatokra és a vendégkör elemzésére. A kérdőívre a 2018-as évben választ adók száma (854fő) jelentősen, 89\%- 
kal meghaladta a 2017-est (452 fó), aminek oka az volt, hogy nagyobb minta elérésének céljából 2018-ban ősszel is folyt a vendégek megkérdezése. Az adatok összehasonlíthatóságát ez nem rontja, ugyanis a kérdőív eredményei alapján a vendégkör a tavaszi és őszi időszakban is azonos tulajdonságokat mutat.

\section{A kérdőívet kitöltók demográfiai és földrajzi jellemzói}

Az eredményeket tekintve elmondható, hogy a megkérdezett vendégek többsége belföldről érkezett, azonban 74\%-os arányuk 2018-ra 63\%-ra csökkent (így értelemszerúen a külföldiek aránya 37\%-ra nőtt a 2017-es 26\%-kal szemben). Ahogyan az az 1. táblázatban is látható, a megkérdezett külföldi vendégek esetén mindkét évben egyértelmú volt a német nyelvterületről érkezők túlsúlya, azonban a németországi vendégeknek az összes kitöltőhöz viszonyított aránya 2018-ban jelentősen kisebb volt. Kiemelkedően negatív a fürdő vendégkörének tekintetében, hogy a közvetlen szomszédságból - 10 percen belül elérhető az országhatár - a szlovén vendégkör riasztóan alacsony számban van jelen.

1. táblázat-Table 1

A kérdőívet kitöltő külföldi vendégek megoszlása

Distribution of foreign visitors completing the questionnaire

\begin{tabular}{|c|c|c|c|c|}
\hline & \multicolumn{2}{|c|}{2017} & \multicolumn{2}{|c|}{2018} \\
\hline & fó & $\%$ & fö & $\%$ \\
\hline Ausztria & 55 & 47,0 & 215 & 67,0 \\
\hline Németország & 25 & 21,0 & 26 & 8,0 \\
\hline Szlovénia & 5 & 4,0 & 15 & 5,0 \\
\hline Horvátország & 0 & 0,0 & 3 & 0,9 \\
\hline Csehország & 1 & 1,0 & 47 & 14,7 \\
\hline Hollandia & 0 & 0,0 & 3 & 0,9 \\
\hline Szlovákia & 1 & 1,0 & 2 & 0,6 \\
\hline Nincs adat & 30 & 26,0 & 9 & 2,9 \\
\hline Összesen & 117 & 100,0 & 320 & 100,0 \\
\hline
\end{tabular}

Forrás: szerk. Vizi I.-STRACK F.

Source: ed. by VIZI, I.-STRACK, F.

A belföldi vendégek tekintetében egy további földrajzi eredet szerinti megoszlás - helyi lakosok és további belföldi vendégek - került vizsgálatra. A 3. ábrán megfigyelhetô, hogy a 2018-as nagyobb elemszámú mintában értelemszerúen magasabb ugyan a helyi lakosok aránya, azonban a 2017-es évhez képest csupán minimális a különbség az arányokat illetően. A 2017-es megkérdezés során a tavaszi időszakban volt a legmagasabb a helyi, Lentiben élő vendégek száma, míg 2018-as adatokat tekintve a nyári időszakról mondható el ugyanez. A felmérésben a lenti lakosság közül a bérlettel rendelkező törzsvendégek voltak elsősorban elérhetők. A városka esetében is érvényesül az a tény, hogy a helyi lakosok jellemzően kevésbé részesítik előnyben saját lakókörnyezetük fürdőjét (nagy városok esetében ez a jelenség hatványozottabb, hiszen a turisztikai kínálat elérése egyben az elmozdulás élményét is adja).

A kitöltők nemi hovatartozásának vizsgálatakor beigazolódott, hogy a nők magasabb hajlandóságot tanúsítanak az ilyen típusú önkéntes adatszolgáltatásokban, felmérésekben való részvételre, így a kérdezőbiztosnak nagyobb esélye van kommunikációt kezdemé- 

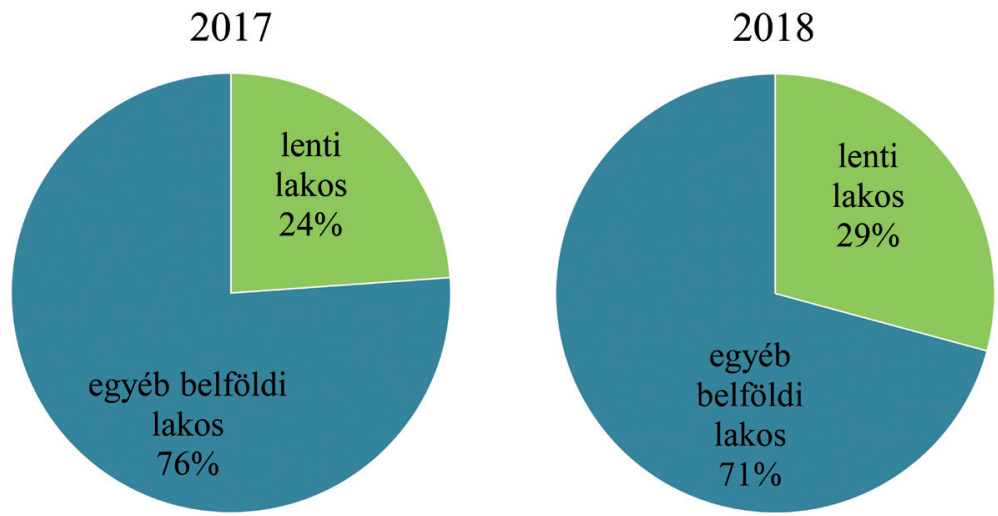

3. ábra A kérdőívet kitöltő belföldi vendégek lakóhely szerinti megoszlása. Forrás: szerk. VIZI I.-STRACK F.

Figure 3 Distribution of domestic visitors in the questionnaire by place of residence. Source: ed. by VizI, I.-STRACK, F.

nyezni az eredményes kitöltés érdekében. Azonban a 2. táblázatban látható az is, hogy 2018-ban növekedett a férfi válaszadók száma, az előző évi 42\%-ról 47\%-ra. Csak a férfi és női válaszadók arányát tekintve 2018-ban a női válaszadók aránya a nemüket megadók egészéhez képest 51,90\%,2017-ben pedig 55,73\%. A nemre vonatkozó kérdésnél hiányzó válaszok (,nincs válasz”) kérdezőbiztosi hibának tekinthetők, ez a hibaszám 2018-ban a 2017-es felére csökkent.

2. táblázat-Table 2

A kérdőívet kitöltő vendégek nemek szerinti megoszlása

Gender breakdown of guests completing the questionnaire

\begin{tabular}{lrrrrr}
\hline & \multicolumn{1}{c}{$\mathbf{2 0 1 7}$} & & \multicolumn{1}{c}{$\mathbf{2 0 1 8}$} & \multicolumn{1}{c}{ fö } & \multicolumn{1}{c}{} \\
\hline Férfi & 189 & 42 & 405 & 47 \\
Nó & 238 & 53 & 437 & 51 \\
Nincs válasz & 25 & 6 & 12 & 1 \\
Összesen & $\mathbf{4 5 2}$ & $\mathbf{1 0 0}$ & $\mathbf{8 5 4}$ & $\mathbf{1 0 0}$ \\
\hline
\end{tabular}

Forrás: szerk. Vizi I.-STRACK F.

Source: ed. by VIZI, I.-STRACK, F.

A kérdőívet kitöltő vendégek iskolai végzettségének elemzése során a két év adatainak összevetésekor változás volt megfigyelhető. 2018-ban a kérdésre 113 fő (13\%) nem adott választ, míg 2017-ben ez 86 fó (19\%) volt. Látható tehát, hogy a minta elemszámához képest 2018-ban javult a kérdésre válaszolók aránya. 2018-ban a válaszadók 39\%-a rendelkezett felsőfokú végzettséggel a 2017. évi 29\%-kal szemben, ilyen téren tehát jelentős különbség tapasztalható (4. ábra).

A megkérdezettek az életkoruk megadását illetően kevésbé voltak elutasítók, mint az iskolai végzettségük tekintetében. A 2017.évi 4\%-os (19 fó) elutasítással szemben 2018-ban mindössze a megkérdezettek 1\%-a (10 fö) utasította el a válaszadást. Az életkor nem sávos módszerrel került lekérdezésre, a kérdezőbiztosok a válaszadó pontos életkorát jegyezték fel, az eredmények az 5. ábrán láthatók. A kérdőívet kitöltők átlagéletkora 2017-ben 52,6, 2018-ban pedig 48,4 év volt. 
2017

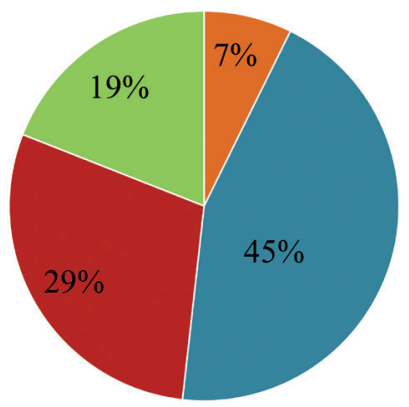

- alapfokú

- felsőfokú
2018

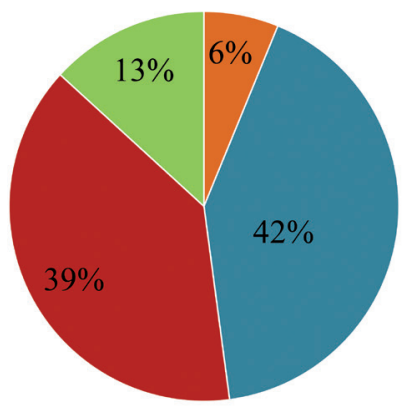

- középfokú

- nincs válasz

4. ábra A kitöltők iskolai végzettség szerinti megoszlása. Forrás: szerk. Vizi I.-STRACK F. Figure 4 Distribution of respondents by educational attainment. Source: ed. by Vizi, I.-STRACK, F.

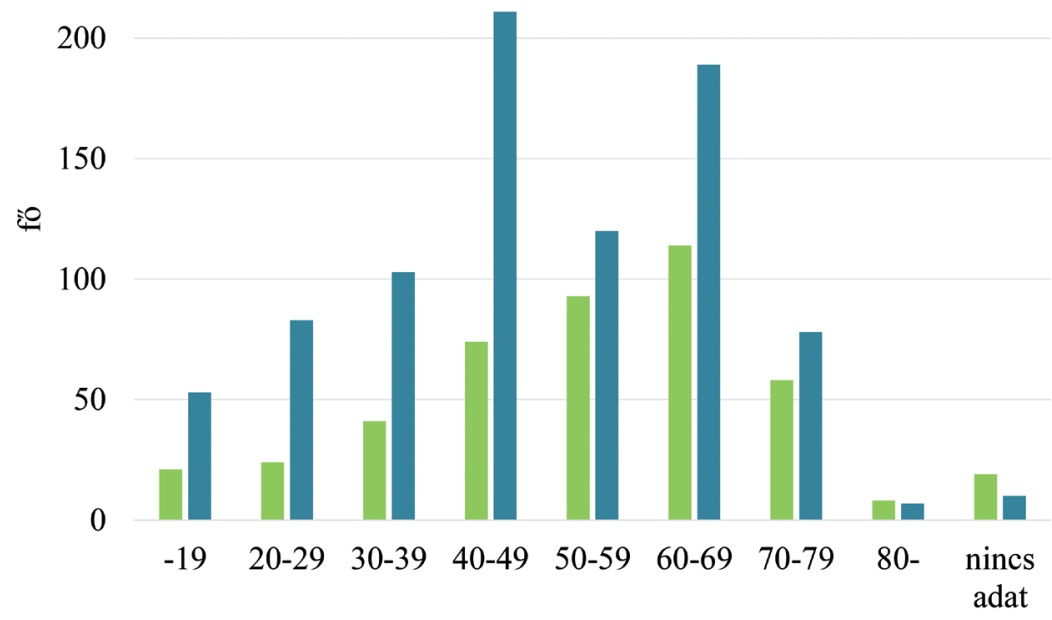

$\because 2017 \backsim 2018$

5. ábra A kérdőívet kitöltők életkor szerinti megoszlása. Forrás: szerk. VIZI I.-STRACK F.

Figure 5 Distribution of the respondents by age. Source: ed. by Vizi, I.-STRACK, F.

A kutatás eredményei alapján egyértelmúen látszik, hogy a fürdőnek jól érzékelhető, visszajáró vendégköre van. Mindkét vizsgált évet figyelembe véve megállapítható, hogy a megkérdezett vendégek többsége - 2017-ben 58\%, 2018-ban pedig 70\%. - visszatérő látogató volt; közülük mindkét évben azok voltak többségben, akik a megkérdezést megelőzően már több mint öt alkalommal jártak a Lenti Termálfürdó és Szent György Energiaparkban. Ez alapján kimondható, hogy stabil, jelentôs visszatérő vendégkörrel rendelkezik a fürdő, akik átlagéletkorukat tekintve 49,5 évesek. 
A kutatás során kitértünk annak a vizsgálatára is, hogy a vendégek az adott időszakokban honnan (mely Lentiben található szálláshelyről) érkeztek a fürdőbe, illetve milyen típusú vendégekról van szó (6.ábra).

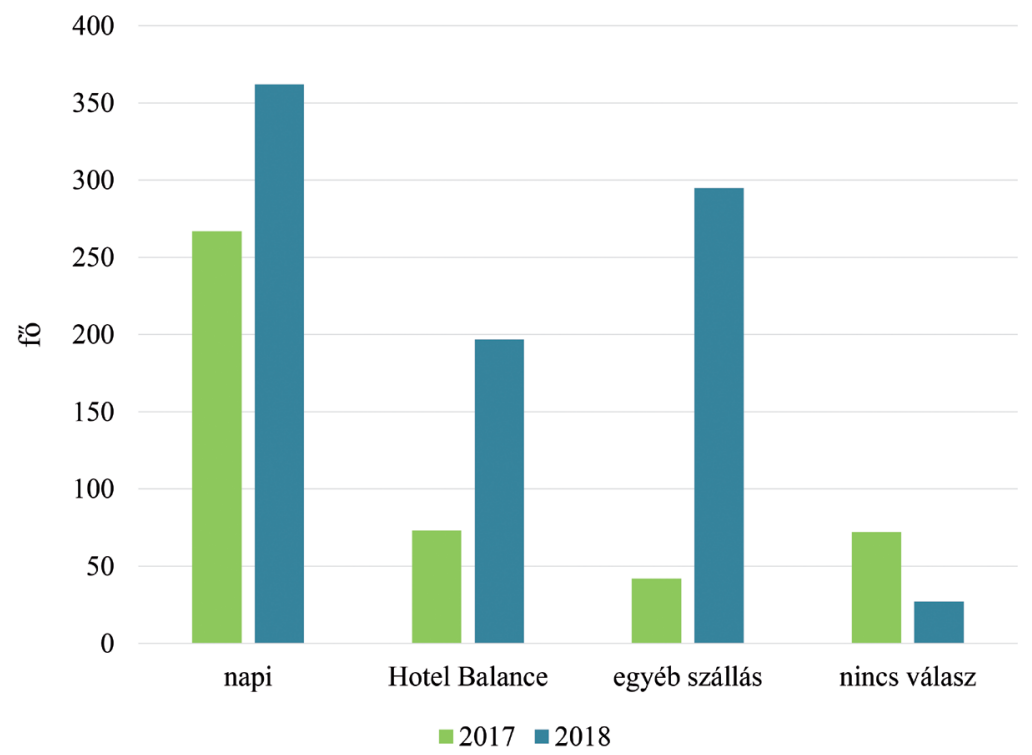

6. ábra A kérdőívet kitöltők érkezésének megoszlása (2017 és 2018). Forrás: szerk. VIZI I.-STRACK F. Figure 6 Distribution of arrival of the respondents (2017 and 2018). Source: ed. by Vizi, I.-STRACK, F.

Szembetűnő, hogy 2018-ban jóval magasabb az egyéb szálláshelyről a fürdőbe érkezők aránya. Érdemes tehát további kategóriákra bontani a 2018-ban egyéb szálláshelyekrôl a fürdőbe érkező 295 fó adatait és az általuk adott válaszokat. Az egyéb szállást megjelölt vendégek 30\%-a valamiféle apartmanból, 11\% -a kempingből, 25\%-a a Termál Panzióból, $7 \%$-a a Zéta Hotelből, további $27 \%$-a pedig egyéb, a felsoroltaktól is különböző helyről érkezett a fürdőbe.

\section{Vendégelégedettség}

Általánosságban elmondható, hogy a vendégelégedettséggel kapcsolatos kérdésekre adott válaszok pozitívak, a vendégek magas pontszámokat adtak és néhány elemtől eltekintve kijelenthetjük, hogy mindkét vizsgált évet tekintve elégedettek voltak a fürdővel.

A vendéget az adott attrakcióhoz való megérkezéskor éró hatások, illetve tapasztalatok különösen fontosak, hiszen nagymértékben meghatározzák a teljes tartózkodás hangulatát, illetve az azzal való elégedettséget. Éppen ezért nagyon fontos azoknak a fürdőhöz kapcsolódó szolgáltatásoknak a vizsgálata, amelyekkel a vendég a megérkezés közben, vagy akár közvetlenül utána találkozik. A kérdőív ehhez kapcsolódó kérdései esetén a válaszadók a 2017-es évben ötelemú (ahol 5=nagyon elégedett, 1=elégedetlen), a 2018-as évben pedig tízelemú (ahol 10 =nagyon elégedett, 1 =elégedetlen) Likert-skálán értékelhették az egyes szolgáltatásokat. A vendégelégedettség vizsgálata során három, egymástól különböző vendégcsoportot hasonlítottunk össze. A vendégek által adott ,,pontszámokat” átlagoltuk, majd összehasonlíthatóság érdekében a 2017-es évben kapott adatokat 10-es skálára átszámoltuk és így összesítettük az alábbi táblázatokban. 
A 3.táblázatban látható, hogy a külföldi és a belföldi vendégek véleménye közel azonos maradt a vizsgálat éveiben, mindössze a vendégtájékoztatás minősége esetében figyelhető meg javulás a külföldiek, valamint romlás a belföldiek esetében. Továbbá megállapítható, hogy a külföldi vendégek a belföldiekhez képest 2017-ben alacsonyabbnak ítélték meg a szolgáltatások minőségét. Szakmai oldalról tekintve ez objektív eredménynek tekinthetô, hiszen az elsősorban ausztriai küldőterületről érkező vendégek minőséggel kapcsolatos elvárásai az általános osztrák életszínvonalbeli és fürdőhasználati szokások alapján fogalmazódnak meg. Még akkor is érvényes ez, ha elsősorban az alacsonyabb ár miatt választják a vizsgálatban szereplő fürdőt. Mindeközben a külföldi válaszadók jobbnak ítélték meg a 2017. évi állapotokhoz képest a szolgáltatás minőségét, ami annak volt köszönhető, hogy a 2017. évi vendégelégedettségi vizsgálatok eredményei beépültek a menedzsment minőségbiztosítási tevékenységébe és a munkavállalók ennek szellemiségében javítottak a minőségen. Figyelemre méltó, hogy a helyi, lenti lakosok értékelése a 2017-es évhez képest viszont minden területen jelentôsen romlott. Mégis miért ítélte meg a fürdőbérlettel fürdőbejáró helyi lakosság alacsonyabb értékűre - több esetben a 2017. évi külföldi értékek alá pontozva - a minőséget? Ennek egyik magyarázata meglepő módon abban található meg, hogy a bérletet vásárlók 2018-ban a bérletekhez kapcsolódóan további ingyenes szolgáltatásokhoz jutottak, mégpedig bónusz ajándékként meghatározott számú szaunabelépőt és ugyancsak meghatározott számú, az új élményfürdőbe szóló belépőt kaptak (mert egyébként mindkét fürdőrészleg az alap-belépőjegyen felül megváltandó, kiegészítő jeggyel érhető el); a bérletvásárlók jelentős része azonban cserélgetni szerette volna a két ingyenesen kapott szolgáltatást, amihez - teljesen érthetően - a fürdő menedzsmentje nem járult hozzá. Ez viszont a helyi vendégkörben érzelmi és hangulati feszültséget okozott és visszatükröződött a vendégelégedettségi mérések eredményében.

3. táblázat - Table 3

A válaszadók elégedettsége megérkezéskor egy 1-10 közötti skálán kifejezve Respondents' satisfaction on arrival expressed on a scale 1 to 10

\begin{tabular}{lcccccccc}
\hline & \multicolumn{2}{c}{$\begin{array}{c}\text { Parkolási } \\
\text { lehetóség }\end{array}$} & \multicolumn{2}{c}{ Parkosítás } & \multicolumn{2}{c}{$\begin{array}{c}\text { Recepció - } \\
\text { pénztár }\end{array}$} & \multicolumn{2}{c}{$\begin{array}{c}\text { Vendégtájékoztatás } \\
\text { minósége }\end{array}$} \\
& $\mathbf{2 0 1 7}$ & $\mathbf{2 0 1 8}$ & $\mathbf{2 0 1 7}$ & $\mathbf{2 0 1 8}$ & $\mathbf{2 0 1 7}$ & $\mathbf{2 0 1 8}$ & $\mathbf{2 0 1 7}$ & $\mathbf{2 0 1 8}$ \\
\hline Külföldi & 9,18 & 9,22 & 9,24 & 9,29 & 9,02 & 9,29 & 8,88 & 9,30 \\
Belföldi & 9,46 & 9,28 & 9,46 & 9,30 & 9,32 & 9,31 & 9,16 & 9,35 \\
Lenti & 9,48 & 8,90 & 9,56 & 8,92 & 9,48 & 9,09 & 9,26 & 8,98 \\
\hline
\end{tabular}

Forrás: szerk. VIZI I.-STRACK F.

Source: ed. by VIZI, I.-STRACK, F.

A fürdőbe való megérkezést követően a vendégek elégedettségét nagymértékben befolyásolja az adott szolgáltató, jelen esetben a fürdő személyzete. A recepciós-pénztáros munkakör kiemelkedően fontos, hiszen a recepción dolgozó személyekkel találkozik elsőként a vendég. A vendégvélemények azt mutatják (4 táblázat), hogy a vendégek 2017ben és 2018-ban egyaránt a recepciósok-pénztárosok előzékenységével voltak legkevésbé elégedettek. Miközben 2017-ben a külföldieknél volt ez elsősorban probléma, 2018-ban inkább a helyi lakosság esetén jelenik meg hangsúlyosabban. 2018-ban az előzékenység, segítőkészség és szakszerúség (ebben a sorrendben) volt a leginkább kifogásolt a pénztáros-recepciós munkakörök tekintetében. 2017-ben ugyanez volt a helyzet, annyi különbséggel, hogy a szakszerúség egy árnyalattal jobbnak lett értékelve. 
A válaszadók személyzettel (recepciós-pénztáros) kapcsolatos elégedettsége egy 1-10 közötti skálán kifejezve

Respondents' satisfaction with staff regarding the receptionists and cashiers expressed on a scale 1 to 10

\begin{tabular}{lcccccccccccc}
\hline & \multicolumn{3}{c}{ Udvariasság } & \multicolumn{2}{c}{$\begin{array}{c}\text { Szak- } \\
\text { szerúség }\end{array}$} & \multicolumn{2}{c}{ Előzékeny- } & \multicolumn{2}{c}{$\begin{array}{c}\text { Segító- } \\
\text { készség }\end{array}$} & \multicolumn{2}{c}{ Ápoltság } & \multicolumn{2}{c}{$\begin{array}{c}\text { Munka- } \\
\text { ruházat }\end{array}$} \\
& $\mathbf{2 0 1 7}$ & $\mathbf{2 0 1 8}$ & $\mathbf{2 0 1 7}$ & $\mathbf{2 0 1 8}$ & $\mathbf{2 0 1 7}$ & $\mathbf{2 0 1 8}$ & $\mathbf{2 0 1 7}$ & $\mathbf{2 0 1 8}$ & $\mathbf{2 0 1 7}$ & $\mathbf{2 0 1 8}$ & $\mathbf{2 0 1 7}$ & $\mathbf{2 0 1 8}$ \\
\hline Külföldi & 9,14 & 9,38 & 9,08 & 9,39 & 8,96 & 9,40 & 9,10 & 9,44 & 9,20 & 9,48 & 9,32 & 9,53 \\
Belföldi & 9,56 & 9,74 & 9,44 & 9,48 & 9,42 & 9,44 & 9,54 & 9,43 & 9,64 & 9,50 & 9,56 & 9,51 \\
Lenti & 9,70 & 9,46 & 9,50 & 9,44 & 9,62 & 9,28 & 9,68 & 9,29 & 9,76 & 9,42 & 9,68 & 9,36 \\
\hline
\end{tabular}

Forrás: szerk. VIZI I.-STRACK F.

Source: ed. by VIZI, I.-STRACK, F.

A vendégek a recepciós-pénztáros személyzethez hasonlóan az uszodamesterek munkáját is értékelték. Az uszodamesterek esetén nagy különbségeket nem lehet megállapítani a három vendégcsoport véleményét illetően, minden területen hasonlóan értékelték a munkájukat. Az recepciós-pénztáros munkakörhöz hasonlóan a helyi vendégek az uszodamesterek értékelése során is változtattak a véleményükön 2018-ban. Míg 2017-ben ők értékelték legjobbra az uszodamesterek teljesítményét, addig 2018-ban összességében ők adták a legkevesebb pontot, tehát a legrosszabb értékelést.

A szaunával kapcsolatos kérdéskörre azok a vendégek tudtak válaszolni, akik a külön belépőjegyet megváltották: 2017-ben az összes válaszadó 51,76\%-a, 2018-ban pedig a kitöltôk 69,20\%-a (5. táblázat). A két év eredményei tekintetében a belföldi vendégek alacsonyabb értékelése a külföldi vendégek minősítéséhez képest azt is mutatja, hogy a szélesebb társadalmi rétegeket elérő, belföldön megindult szaunakultúrához tartozó elemek nem érik el a kívánt minőséget.

A munkaruházat összességében a legalacsonyabb értéket kapta a helyi és a belföldi csoportban is (itt érdemes vizsgálni, hogy a felöntések esetében póló nélkül végzett felöntések vagy a munkaruházat egyéb tekintetben nem felel meg az elvárásnak).

5. táblázat-Table 5

A válaszadók személyzettel (szaunamester) kapcsolatos elégedettsége egy 1-10 közötti skálán kifejezve

Respondents' satisfaction with staff regarding the sauna-masters expressed on a scale 1 to 10

\begin{tabular}{lcccccccccccc}
\hline & \multicolumn{3}{c}{ Udvariasság } & \multicolumn{2}{c}{$\begin{array}{c}\text { Szak- } \\
\text { szerúség }\end{array}$} & \multicolumn{2}{c}{ Előzékeny- } & \multicolumn{2}{c}{$\begin{array}{c}\text { Segító- } \\
\text { készség }\end{array}$} & \multicolumn{2}{c}{ Ápoltság } & \multicolumn{2}{c}{$\begin{array}{c}\text { Munka- } \\
\text { ruházat }\end{array}$} \\
& $\mathbf{2 0 1 7}$ & $\mathbf{2 0 1 8}$ & $\mathbf{2 0 1 7}$ & $\mathbf{2 0 1 8}$ & $\mathbf{2 0 1 7}$ & $\mathbf{2 0 1 8}$ & $\mathbf{2 0 1 7}$ & $\mathbf{2 0 1 8}$ & $\mathbf{2 0 1 7}$ & $\mathbf{2 0 1 8}$ & $\mathbf{2 0 1 7}$ & $\mathbf{2 0 1 8}$ \\
\hline Külföldi & 9,34 & 9,48 & 9,26 & 9,36 & 9,18 & 9,39 & 9,36 & 9,43 & 9,32 & 9,47 & 9,42 & 9,43 \\
Belföldi & 9,64 & 9,47 & 9,58 & 9,39 & 9,58 & 9,41 & 9,60 & 9,37 & 9,60 & 9,38 & 9,54 & 9,32 \\
Lenti & 9,56 & 9,44 & 9,56 & 9,35 & 9,56 & 9,35 & 9,56 & 9,31 & 9,62 & 9,32 & 9,44 & 9,13 \\
\hline
\end{tabular}

Forrás: szerk. Vizi I.-STRACK F.

Source: ed. by VIzI, I.-STRACK, F. 
A fürdőkben az időtöltés jellegéből adódóan kiemelkedően fontos a tisztaság kérdése, különösen az egészségturizmusban érdekelt vendég utazással kapcsolatos döntését illetően, ha strandot, fürdőt, gyógyfürdőt óhajt meglátogatni. A 6. táblázat a kérdőívet megválaszoló vendégek tisztasággal kapcsolatos értékelését foglalja össze. Ebben a kérdéskörben az egyes helyszínek kapcsán 2017-ben jellemzően a helyi lakosok adták a legmagasabb pontszámot, azonban 2018-ban már minden esetben ők értékelték legrosszabbra a tisztaságot.

6. táblázat - Table 6

A válaszadók tisztasággal kapcsolatos elégedettsége egy 1-10 közötti skálán kifejezve

Respondents' satisfaction with cleanliness expressed on a scale 1 to 10

\begin{tabular}{|c|c|c|c|c|c|c|c|c|c|c|}
\hline & \multicolumn{2}{|c|}{$\begin{array}{l}\text { Szociális } \\
\text { blokkok }\end{array}$} & \multicolumn{2}{|c|}{ Medencék } & \multicolumn{2}{|c|}{$\begin{array}{l}\text { Medence- } \\
\text { terek }\end{array}$} & \multicolumn{2}{|c|}{ Folyosók } & \multicolumn{2}{|c|}{$\begin{array}{c}\text { Gyógyászati } \\
\text { kezelő-helyiségek }\end{array}$} \\
\hline & 2017 & 2018 & 2017 & 2018 & 2017 & 2018 & 2017 & 2018 & 2017 & 2018 \\
\hline Külföldi & 8,84 & 9,09 & 8,92 & 9,10 & 8,98 & 9,11 & 8,90 & 9,13 & 8,98 & 9,16 \\
\hline Belföldi & 9,46 & 9,13 & 9,44 & 9,19 & 9,44 & 9,17 & 9,48 & 9,13 & 9,54 & 9,08 \\
\hline Lenti & 9,36 & 8,80 & 9,56 & 8,89 & 9,52 & 8,87 & 9,60 & 8,82 & 9,74 & 8,60 \\
\hline
\end{tabular}

Forrás: szerk. Vizi I.-STRACK F.

Source: ed. by VIZI, I.-STRACK, F.

A válaszadók a fürdő mellékhelyiségeinek tisztaságát is értékelhették. Ez esetben ismételten a helyi lakosok adták a legalacsonyabb pontszámokat, a legpozitívabbak pedig a külföldi látogatók voltak. A 2017-es és 2018-as értékelések közötti fordulat ebben az esetben is tapasztalható.

\section{Az összefüggésvizsgálatok eredményei}

Az összefüggésvizsgálatok során azt vizsgáltuk, hogy a vendégek demográfiai adatai közül a „nem”, a „lakóhely”, a „végzettség”, illetve az „életkor” adatok milyen kapcsolatban állnak a vendégek elégedettségével. A módszert fentebb A kutatás módszertana c. fejezetben már ismertettük, röviden megismételve az első három demográfiai adattípus esetén kereszttábla-elemzést, az ,életkor” esetén pedig rangkorrelációt alkalmaztunk. A 7. táblázatban összegzett eredmények alapján megállapítható, hogy a vendégek neme és elégedettségi szintje között három eset kivételével gyenge, de szignifikáns kapcsolat mutatható ki. A lakóhely esetén minden esetben szignifikáns kapcsolat figyelhető meg, azonban ezek a kapcsolatok is gyengék. A végzettség tekintetében az elemzés az esetek többségében gyenge szignifikáns kapcsolatot mutatott ki.

Az életkoradatok vizsgálata során kimutatott szignifikáns kapcsolatok mindegyike közepesen erős, egy részük negatív, más részük pedig pozitív irányú. A negatív irányú kapcsolatok közül kiemelkedik az életkor és a recepciós-pénztáros személyzet udvariasságának kapcsolata, amely azt jelenti, hogy minél fiatalabb volt egy vendég, annál elégedettebb volt a recepciós-pénztáros munkakörben dolgozók udvariasságával. A vizsgálat egy esetben, a gyógyászati kezelőhelyiségek tisztasága esetén mutatott ki pozitív irányú kapcsolatot. Ez azt jelenti, hogy minél idősebb volt egy vendég, annál elégedettebb volt a gyógyászati kezelőhelyiségek tisztaságával. 
Az összefüggésvizsgálatok eredményei

Results of the correlational study

\begin{tabular}{|c|c|c|c|c|c|}
\hline \multicolumn{2}{|c|}{ Elégedettség } & Nem & $\begin{array}{r}\text { Lakóhely } \\
\text { S }\end{array}$ & $\begin{array}{l}\text { Végzettség } \\
\text { zerint }\end{array}$ & Életkor \\
\hline \multirow{4}{*}{$\begin{array}{l}\text { Első benyomások } \\
\text { a fürdőbe } \\
\text { érkezésekor }\end{array}$} & Parkolási lehetőség & - & 0,199 & 0,137 & - \\
\hline & Parkosítás & 0,127 & 0,203 & 0,118 & - \\
\hline & Recepció - pénztár & 0,111 & 0,198 & 0,114 & - \\
\hline & Vendégtájékoztatás minősége & 0,120 & 0,183 & 0,113 & - \\
\hline \multirow{4}{*}{$\begin{array}{l}\text { Az öltözők } \\
\text { állapota }\end{array}$} & Tisztaság & 0,158 & 0,179 & 0,118 & - \\
\hline & Praktikusság/Használhatóság & 0,154 & 0,176 & 0,105 & - \\
\hline & Zuhanykabinok tisztasága & 0,154 & 0,187 & - & - \\
\hline & Toalett tisztasága & 0,147 & 0,184 & 0,112 & - \\
\hline \multirow{6}{*}{$\begin{array}{l}\text { Kiszolgáló } \\
\text { személyzet } \\
\text { (recepciós- } \\
\text { pénztáros) }\end{array}$} & Udvariasság & 0,115 & 0,205 & 0,115 & $-0,650$ \\
\hline & Szakszerúség & 0,122 & 0,180 & 0,105 & - \\
\hline & Előzékenység & 0,112 & 0,197 & 0,110 & $-0,420$ \\
\hline & Segítőkészség & 0,111 & 0,199 & - & $-0,460$ \\
\hline & Ápoltság & 0,124 & 0,203 & 0,101 & $-0,490$ \\
\hline & Munkaruházat & 0,130 & 0,178 & - & $-0,450$ \\
\hline \multirow{6}{*}{$\begin{array}{l}\text { Kiszolgáló } \\
\text { személyzet } \\
\text { (uszodamester) }\end{array}$} & Udvariasság & 0,107 & 0,184 & 0,114 & $-0,430$ \\
\hline & Szakszerűség & 0,108 & 0,184 & 0,105 & - \\
\hline & Előzékenység & 0,135 & 0,205 & 0,108 & - \\
\hline & Segítőkészség & 0,132 & 0,195 & 0,114 & - \\
\hline & Ápoltság & 0,123 & 0,191 & - & - \\
\hline & Munkaruházat & 0,117 & 0,181 & 0,106 & - \\
\hline \multirow{6}{*}{$\begin{array}{l}\text { Kiszolgáló } \\
\text { személyzet } \\
\text { (szaunamester- } \\
\text { szaunakezelő) }\end{array}$} & Udvariasság & 0,131 & 0,241 & - & - \\
\hline & Szakszerúség & - & 0,262 & 0,133 & - \\
\hline & Előzékenység & 0,148 & 0,248 & - & - \\
\hline & Segítókészség & 0,149 & 0,221 & 0,133 & - \\
\hline & Ápoltság & 0,141 & 0,261 & 0,131 & - \\
\hline & Munkaruházat & - & 0,221 & - & - \\
\hline \multirow{4}{*}{$\begin{array}{l}\text { A fürdő } \\
\text { mellékhelyiségei }\end{array}$} & Illatok-szagok & 0,130 & 0,196 & 0,119 & - \\
\hline & Üveg-tükörfelületek tisztasága & 0,123 & 0,202 & 0,111 & - \\
\hline & Járólapok tisztasága & 0,113 & 0,183 & 0,113 & - \\
\hline & Higiéniás eszközök megléte & 0,125 & 0,183 & 0,117 & - \\
\hline \multirow{5}{*}{$\begin{array}{l}\text { A fürdő } \\
\text { tisztasága }\end{array}$} & Szociális blokkok & 0,134 & 0,196 & 0,113 & - \\
\hline & Medencék & 0,108 & 0,195 & - & - \\
\hline & Medenceterek & 0,132 & 0,212 & 0,119 & - \\
\hline & Folyosók & 0,141 & 0,180 & 0,099 & - \\
\hline & Gyógyászati kezelőhelyiségek & 0,162 & 0,222 & 0,128 & 0,560 \\
\hline
\end{tabular}

Forrás: szerk. VIZI I.-STRACK F.

Source: ed. by VIZI, I.-STRACK, F. 


\section{Összefoglalás}

A magyarországi fürdők a hazai egészségturizmus és egyben Magyarország jelentős imázseszközei belföldön és nemzetközi viszonylatban is, építészeti és múszaki állapotukban, az ott dolgozó munkatársakkal együtt. A magyar fürdőkultúra több száz éves tradicionális hagyományai, a 20-21. századi infrastruktúra, a gazdasági-társadalmi és turisztikai környezet igényli és elvárja a fürdőktől, hogy vendégbarát szolgáltató komplexumként jelenjenek meg a település, a régió, illetve az ország turisztikai kínálatában.

A kutatás eredményei alapján jól meghatározhatóvá vált a Lenti Termálfürdő tipikus vendégköre. A beérkezett adatokra támaszkodva az mondható, hogy a lenti fürdő belföldi vendégeinek több mint kétharmada nem helyi lakos (lehetnek kirándulók és turisták egyaránt), a férfiak és nők aránya pedig kiegyenlített. A fürdőt jellemzően közép-, illetve felsőfokú végzettséggel rendelkező személyek látogatják, e két csoport pedig közel azonos arányban jelenik meg. A vendégek többsége középkorú, 40-69 éves. A vendégelégedettség kapcsán megfigyelhető, hogy a külföldi vendégek a fürdőről alkotott véleménye 2017-ről 2018-ra összességében javult, míg a belföldieké, valamint a helyi, lenti lakosoké romlott. A legnagyobb változás a helyi lakosok értékelései kapcsán figyelhető meg. A vendégelégedettség javulásának, illetve romlásának többféle oka lehet.

A felmérés azt is megvizsgálta, hogy a jelenlegi vendégkör milyen változó véleménynyel rendelkezik a fürdőről. Feltárta, hogy a helyi lakosság életében és életminőségében miként játszik szerepet a különböző jellegú támogatás a fürdő szolgáltatásainak igénybevétele során.

A felmérés rávilágított arra is, hogy a külföldi vendégkör kritikusabb szemmel (kimondható, hogy objektívebben) nézi a szolgáltatások minőségét. A külföldi (főleg osztrák és német) vendégek minősítéseinek megfogalmazásánál nem szabad elfelejteni, hogy egy alacsonyabb színvonalú, gyengébb minőségű szolgáltatásrendszert választottak a saját megszokott rendszerükhöz képest a kedvező ár miatt (az átlagos árkülönbség jellemzốn kétszeres-ötszörös tartományban van, sajnos a magyarországi helyszínek oldaláról tekintve alacsonyabban).

Kiemelendő még, hogy a fürdőt jellemzően bérlettel látogató helyieknek, Lenti kisváros lakosainak a véleménye és elégedettsége 2017-ről 2018-ra egyértelmúen romlott. A kutatás eredményének lényeges eleme, hogy a helyi lakosság 2018-as alacsonyabb értékelése nem a szolgáltatási minőség romlásának, hanem egyes szolgáltatások értékesítési rendjében történt változásoknak volt köszönhető, mert azok érzelmi és hangulati feszültséget okoztak a bérletes vendégek esetében.

A vendégelégedettségi felmérés mindemellett betöltötte és minden bizonnyal a jövőbeni felmérések esetében is be fogja tölteni azt a szerepet, hogy a tervezett fejlesztésekhez megfelelő vendégoldali véleményt adjon. Jelen felmérés megerősítette a fürdő menedzsmentjét és tulajdonosát abban, hogy a pontos fejlesztési irányvonalaknak és a lehatárolt célszegmenseknek köszönhetően a fürdő kínálata olyan irányban tudott és fog tudni a jövőben fejlődni, amely pótolta, pótolja a korábbi évek hiányosságait, a fürdő így szakmailag megalapozott irányban tud a tervezett fejlesztések révén hosszú távú fejlődési pályára állni.

\footnotetext{
VIZI IsTVÁN

Pannon Egyetem, Veszprém

vizi.istvan@gtk.uni-pannon.hu
} 
STRACK FLÓRIÁN

Pannon Egyetem, Veszprém

strack.florian@gtk.uni-pannon.hu

\section{IRODALOM}

BABBIE, E. 2000: A társadalomtudományi kutatás gyakorlata (5. kiadás). - Balassi Kiadó, Budapest. 704 p. Bookman, M. Z.-Bookman, K. R. 2007: Medical tourism in developing countries. - Palgrave Macmillan, New York. 245 p.

Boros Sz.-Printz-Markó E.-Priszinger K. 2011: Egészségturizmus. - In: Michalkó G. (szerk.): Turisztikai terméktervezés és fejlesztés. Pécsi Tudományegyetem, Pécs. http://www.eturizmus.pte.hu/szakmai-anyagok/ Turisztikai\%20term\%C3\%A9ktervez\%C3\%A9s\%20\%C3\%A9s\%20fejleszt\%C3\%A9s/book.html

CONNELL, J. 2011: Medical tourism. - CAB International, Wallingford. 208 p.

DeMicco, F. J. (szerk.) 2017: Medical tourism and wellness: hospitality bridging healthcare (H2H). - Apple Academic Press, Waretown. 480 p.

Dunn, H. L. 1961: High-level wellness. - R. W. Beatty Ltd., Arlington. 256 p.

FIDY J.-MAKARA G. 2005: Biostatisztika. - Digitális Tankönyvtár. Informed 2002 Kft. https://regi.tankonyvtar.hu/hu/tartalom/tkt/biostatisztika-1/pt01.html

KARDOS Z.-NÉ 2011: Turisztikai ismeretek. - Digitális Tankönyvtár. 109 p. https://regi.tankonyvtar.hu/hu/tartalom/tamop425/0034_turisztikai_ismeretek/turisztikai_ismeretek_109_109.html

LACZKó T.-BÁNHIDI M. 2015: Sport és egészségturizmus alapjai.-Pécsi Tudományegyetem, Pécs. 254 p. https:// www.etk.pte.hu/protected/OktatasiAnyagok/\%21Palyazati/sport/SportEgturizmus_elektronikusK3.pdf

Majoros P. 2011: Tanácsok, tippek, trükkök nem csak szakdolgozatíróknak: avagy a kutatásmódszertan alapjai. - Perfekt Gazdasági Tanácsadó Oktató és Kiadó Zrt. Budapest. 336 p.

Müller, H.-LANZ KAUfMANN, E. 2001: Wellness tourism: market analysis of a special health tourist segment and implications for the hotel industry. - Journal of Vacation Marketing 7. 1. pp. 5-17.

NAGY Sz. 2016: A vendégelégedettség mérése a szállodaiparban.- In: PISKóTi I. (szerk.): Marketingkaleidoszkóp 2016: Tanulmányok a Marketing Intézet kutatási eredményeiből, Miskolci Egyetem Marketing Intézet, Miskolc. pp. 8-87.

Pimpale, V. K. 2016: Medical tourism. - Lulu Publication, Raleigh. 146 p.

RÁTZ T. 2001: Zennis és Lomi Lomi, avagy új trendek az egészségturizmusban.- Turizmus Bulletin 5.4.pp.pp. 11-30.

Reisman, D. A. 2010: Health tourism: social welfare through international trade. - Edward Elgar Publishing Ltd. Northampton. 204 p.

Rudolfné Katona M.-Karakasné Morvay K.-Magyar M. 2008: A szolgáltatásminőség és a vendégelégedettség mérése. - Agora 1. 1. pp. 56-64.

RuSZINKó Á.-DonKA A. 2019: Az egészségturizmus értelmezése a turizmus változó rendszerében. - Turizmus Bulletin 19. 2.pp. 47-57.

SAJtos L.-Mitev A. 2007: SPSS Kutatási és adatelemzési kézikönyv. - Alinea Kiadó, Budapest. 404 p.

Smith, M.-PuCzKó L. 2009: Health and wellness tourism. - Butterworth-Heinemann, Burlington. 416 p.

SzABó Z. 2011: Inanspruchnahme von Heilbad-Dienstleistungen im Lichte von Verbrauchererhebungen. - In: DARABos F. (szerk.): Kincs, ami van - Fókuszban az egészségturizmus. Nyugat-magyarországi Egyetem Kiadó, Győr. pp. 121-134.

SzABÓ Z. 2018: Gyógyfürdő-szolgáltatások vendég-elégedettségi vizsgálata a szarvasi gyógyfürdőben. - In Szabó Z. (szerk.): Fürdővárosok fejlődése. Magyar Fürdővárosok Szövetsége Egyesület, Túrkeve. pp. 39-57.

Szigeti O.-SZAKály Z. 2011: Marketing. - Kaposvári Egyetem, Kaposvár. 49 p.

SzIVA I. 2010: Öntsünk tiszta vizet... Az egészségturizmus fogalmi lehatárolása és trendjeinek válogatott bibliográfiája. - Turizmus Bulletin 14. 4. pp. 73-76.

\section{Egyéb források}

A Lenti Termálfürdő és Szent György Energiapark honlapja. http://lentifurdo.hu/

Központi Statisztikai Hivatal (KSH): http://statinfo.ksh.hu/Statinfo/themeSelector.jsp?lang=hu

Lenti gyógyhelyfejlesztési stratégia 2016. - HÉTFA Kutatóintézet és Elemző Központ, Lenti. 76 p. http://hetfa.eu/wp-content/uploads/2019/01/LENTI-GYO\%CC\%81GYHELYFEJLESZTE\%CC\%81SISTRATE\%CC\%81GIA_20160610_LENTI_VE\%CC\%81GLEGES_KT.pdf

Országos egészségturizmus fejlesztési stratégia 2007.-Az Önkormányzati és Területfejlesztési Minisztérium Turisztikai Szakállamtitkársága megbízásából. Aquaprofit Műszaki, Tanácsadási és Befektetési Rt. Budapest. 172 p. https://2010-2014.kormany.hu/download/b/8e/20000/Egeszsegturizmusstrategia.pdf 